\title{
Virtual Analysis on Proximate Body Composition of Labeo rohita and Cirrhinus mrigala
}

\author{
Muhammad Atif Sikandar ${ }^{1, \mathrm{a}}$, Zaigham Hassan ${ }^{1,2, \mathrm{~b}}$, Abdul Basit ${ }^{3, \mathrm{c}}$, Raees Khan ${ }^{3, \mathrm{~d}, *}$, Fethi Ahmet Ozdemir ${ }^{4, \mathrm{e}}$ \\ ${ }^{1}$ Department of Animal Sciences, Faculty of Biological Sciences, Quaid-i-Azam University, Islamabad 45320, Pakistan \\ ${ }^{2}$ Department of Zoology, University of Peshawar, Khyber Pakhtunkhwa, Pakistan \\ ${ }^{3}$ Department of Plant Sciences, Quaid-i-Azam University, Islamabad 45320, Pakistan \\ ${ }^{4}$ Department of Molecular Biology and Genetics, Faculty of Science and Art, Bingol University, 1200 Bingol, Turkey. \\ * Corresponding author
}

\begin{tabular}{|c|c|}
\hline A R T I C L E I N F O & A B S T R A C T \\
\hline $\begin{array}{l}\text { Keywords: } \\
\text { Labeo rohita } \\
\text { Cirrhinus mrigala } \\
\text { Proximate body composition } \\
\text { Fat } \\
\text { Protein }\end{array}$ & $\begin{array}{l}\text { Labeo rohita and Cirrhinus mrigala are the two Indian major carps and chief components of } \\
\text { polyculture system in the local population. Proximate body composition is the analysis of water, fat, } \\
\text { protein and ash contents of fish. Values are vary considerably within and between species, size, } \\
\text { sexual condition, feeding season and physical activity. The percentage of water is a good indicator } \\
\text { of its relative contents of energy, proteins and lipids. Determination of some proximate profiles such } \\
\text { as protein content, lipid, ash and other nutrients is often necessary to ensure that they are within the } \\
\text { range of dietary requirement and commercial specifications. Based on this background the present } \\
\text { study was aimed to evaluate the nutritional value of some major craps (Labeo rohita and Cirrhinus } \\
\text { mrigala) fishes of Peshawar Carp Hatchery and training centre Sherabad. The proximate } \\
\text { composition of Labeo rohita and Cirrhinus mrigala samples were determined and data was } \\
\text { evaluated statistically by performing t-test through Sigma Plot and graphs were made by using Graph } \\
\text { Pad Prism. The average value of crude protein for Cirrhinus mrigala was found higher than Labeo } \\
\text { rohita (51.7\% and } 39.04 \% \text { ) similarly the water contents were also found higher in Cirrhinus mrigala } \\
\text { than Labeo rohita (75.88\% and } 73.95 \% \text { ). The average value of dry matter and muscle fats contents } \\
\text { were lowered in Cirrhinus mrigala than Labeo rohita ( } 24.11 \% \text { and } 26.04 \% \text { ) and (13.00\% and } \\
13.45 \%) \text { respectively. However, the ash contents were similar in both of experimental species } \\
\text { (23.91\% and } 23.93 \% \text { ). From these results, it is concluded that both Cirrhinus mrigala than Labeo } \\
\text { rohita are very proteineous and have low fats contents so it is very good for the health of consumers. } \\
\text { Further research is recommended on the other parameters and miss rays of this work. }\end{array}$ \\
\hline
\end{tabular}

Further research is recommended on the other parameters and miss rays of this work.

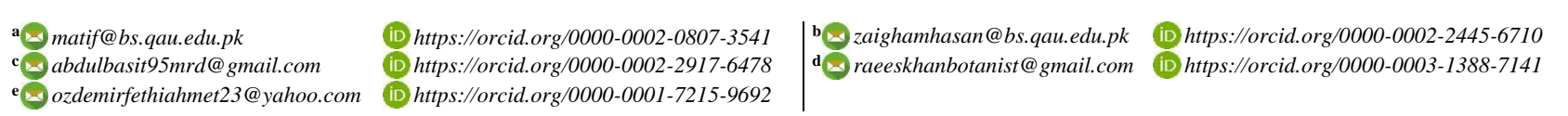

(c) (1) (9) This work is licensed under Creative Commons Attribution 4.0 International License

\section{Introduction}

The science and practice of culturing fish or other aquatic organisms under controlled or semi-controlled conditions is called aquaculture (Ali and Narejo, 2009). Globally, slightly over half $(54 \%)$ of the total food fish supply is obtained from marine and inland capture fisheries. While the remaining $(46 \%)$ is drawn from aquaculture. Globally, aquaculture's contribution to per capita food availability grew from $0.7 \mathrm{~kg}$ in 1970 to $7.8 \mathrm{~kg}$ in 2008. The contribution of capture fisheries to per capita food supply stabilized at $10-11 \mathrm{~kg}$ per capita in the period $1970-2000$, and then declined to $9.3 \mathrm{~b} \mathrm{~kg}$ per capita in 2008. Recent increases in per capita availability are attributed to inland aquaculture (World Aquaculture, 2010). All over the world, aquaculture has become the fastest growing food production sector in the world with an average annual increase of about $10 \%$ since 1984 when compared with $3 \%$ increase for livestock meat and $1.6 \%$ increase for capture fisheries (Umar et al., 2011). Aquaculture in Pakistan is a very new activity and there is huge potential for development due to its rich aquatic resources. The total area under fish ponds is about 60,470 hectares (Akhtar, 2001). In Pakistan it is semi-intensive in nature and is based on composite polyculture of three Indian major carps viz. Rohu, Thaila Mori and two Chinese carps viz. Grass carp (Ctenopharyngodon idella) and silver carp (Hypophthalmichthys molitix). Like India polyculture is quite successful. Fish production is very high than single species culture system and pond quality dos not deteriorate (Sahu et al., 2007). Labeo rohita is commonly known as Rohu. While common name of Cirrhinus mrigala is Mori. 
These two chief components of polyculture system of Indian major carps along with Catla catla. These belong to Cyprinidae family found commonly in rivers and freshwater lakes (Devi and Ali, 2011). Proximate body composition is the analysis of water, fat, protein and ash contents of fish. Carbohydrates and non-protein compounds are present in negligible amount and are usually ignored for routine analysis. The live weight of majority of fishes usually consists of about $70-80 \%$ of water, $20-30$ percent $\%$ and $2-12 \%$ of lipid. However, these values alter considerably within and between species, size, sexual condition, feeding season and physical activity (Aberoumand, 2012). The percentage of water is good indicator of its relative contents of energy, proteins and lipids. The lower the percentage of water would be greater the lipids and protein contents and higher the energy density of the fish. Furthermore, the variations in proximate composition of fish are closely related to the feed intake and the water where they live (Dempson et al., 2004). Data on proximate composition are critical for many applications and investigations on these lines had been carried out since 1880s. Determination of some proximate profiles such as protein content, lipid, ash and other nutrients is often necessary to ensure that they are within the range of dietary requirement and commercial specifications. (Watchman, 2000). Culture of these two fish is common in the local population. It is the first attempt to find the basic nutritional components of these two fish. Based on this background the present study was conducted. This study is carried out to find out the nutritional value of the flesh, compare the nutritional elements and body composition and of Labeo rohita and Cirrhinus mrigala and to decide about the nutritionally better species between the Indian major carps.

\section{Materials and Methods}

The brooder fishes were transported from PCH \& TC in 1:2 water and oxygen ratios. The fishes were acclimatized in the Proximate Analysis Laboratory, Analysis Laboratory Department of Food and Nutrition, the Agriculture University Peshawar, Pakistan. Fishes were slaughtered and $100 \mathrm{~g}$ pellets were taken for proximate analysis. Proximate compositions of fish were determined by conventional method of AOAC (Association of Official Analytical Chemicals) on weight basis (AOAC, 1990). All data was analysed by applying ttest for comparison of two groups through Sigma Plot. Significant change was considered when $\mathrm{P}<0.05$. Data represented in graphs made by Graph Pad Prisim and tables in form of mean and standard error of mean.

\section{Estimation of Moisture}

About 20-30 gram of fresh samples were taken into each known weight basin and weighed in a digital balance (Toledo, Switzerland). The samples were allowed to dry into the oven (Memmet $854 \mathrm{Schwabach}$ ) at $70^{\circ} \mathrm{C}$ for 24 hours in order to remove the moisture until constant weight. After that, the basins are taken out of the oven, cooled in a desiccators and were weighed in a digital balance. Then moistures were calculated by using the following equation (1);

$$
\% \text { of Moisture }=\frac{\text { Weight of loss }}{\text { Weight of Sample taken }} \times 100
$$

\section{Estimation of Protein}

Protein was determined using Kjeildal method which involves digestion, distillation and titration as recommended by AOAC (2001).

Digestion: $0.5 \mathrm{gm}$ sample was weighted. It was taken in a tube and add 2-3 gm catalyst (cuso4 and $\mathrm{K}_{2} \mathrm{SO}_{4}$ ). 7-10 $\mathrm{ml}$ of $\mathrm{H}_{2} \mathrm{SO}_{4}$ was added and placed in the digestion assembly of Fuming Hood $\left(420-430^{\circ} \mathrm{C}\right)$ for 4 hours.

Dilution: Digested sample was cooled. We make volume of $100 \mathrm{ml}$ in volumetric flask by adding distilled water and then store in a bottle for further analysis.

Distillation: $5 \mathrm{ml}$ of sample was taken in a distillation flask. Distilled water was added. $10 \mathrm{ml} \mathrm{NaOH}$ solution was placed on a heater. $10 \mathrm{ml}$ boric acid reagent was taken in receiving flask. Colour of boric acid reagent will change in distillation. Distillation was continued for 7 minutes.

Titration: It was titrated against $0.02 \mathrm{~N} \mathrm{H}_{2} \mathrm{SO}_{4}$ solution. From the titration reading we calculate the $\% \mathrm{~N}$ by the following equation (2);

$$
\begin{aligned}
& \% \text { of } \mathrm{N}_{2}=\frac{(\mathrm{TR}-\mathrm{BR}) \times 0.02 \times 20 \times 100}{\text { Weight of sample taken }} \\
& \mathrm{TR}=\text { Titration reading } \\
& \mathrm{BR}=\text { Blank reading } \\
& \% \text { of protein }=\% \text { of total } \mathrm{N}_{2} \times 6.25
\end{aligned}
$$

\section{Estimation of Fats}

A sample of fish flesh was dried and latter it was dried with the help of morter with the help of pistle, the grounding was done thoroughly, but at the same time care was made to prevent the loss of flesh. The dried sample in powdered form was weighted as $\mathrm{W}_{1}$ now petroleum ether was added to dissolve its fats contents; the petroleum ether is used to extract fats from organic dried sample in powdered form, (Howard and Leonard, 1982). The petroleum ether along with dissolved fats was then removed and the remaining dried samples without fats are again weighted as $\mathrm{W}_{2}$.

Now fats can be estimated by using the following equation (3);

$$
\% \text { of Fat }=\frac{\text { Weight of residue }\left(\mathrm{W}_{2}\right)}{\text { weight of Sample taken }\left(\mathrm{W}_{1}\right)} \times 100
$$

\section{Estimation of Ash}

About 1-2 g fish sample was weighed into a preweighed crucible. The crucible with the contents was heated first over a long flame till all the material was completely churned. Then it was transferred in the Muffle Furnace held at dark red at a rate of $550^{\circ} \mathrm{C}$ for 4 hours until the residue become white. The crucible were cooled in desiccators and weighed. Finally the $\%$ of ash content was calculated by following equation (4):

$$
\% \text { of Ash }=\frac{\text { Weight of fish }}{\text { Weight of Sample taken }} \times 100
$$




\section{Results}

Statistically significant alteration was found in moisture contents of Labeo rohita and Cirrhinus mrigala. The moisture contents of Mori are higher than Rohu $(\mathrm{P}<0.05)$ (Figure 1). The $\mathrm{CP}$ values showed strong significant change between two groups of fishes in this regard. Mori has greater $\mathrm{CP}$ than Rohu $(\mathrm{P}<0.001)$ (Figure 2). In case of Ash contents, no such significant change was found. Ash contents of Rohu has non-significant greater contents of ash than Mori ( $>>0.05)$ (Figure 3). Similarly, no statistically significant difference was found between the input groups. Rohu has non-significant higher fats contents $(\mathrm{P}>0.05)$ (Figure 4). Overall data represented for both fishes as shown in Figure 5. and Table 1.

\section{Discussion}

Fish is widely accepted because of its high deliciousness, low cholesterol and tender flesh (Onyia et al., 2010). However, less number of consumers eats fish because of its nutritional value. It is therefore necessary to make information available to consumers and fishery workers on the nutritional contribution of some fish species in their diets (Adewoye et al., 2003). The biochemical composition of a fish is the consequence of complex interactions between biological and physical characteristics like sex, size, reproductive stage, temperature and food availability (Javaid, 1992). Many reports are available on biochemical composition of fish muscle with reference to annual growth, season, migration and spawning (Basade et al., 2000). The current observation is also a part of such type of study. The proximate composition of Labeo rohita and Cirrhinus mrigala were compared. The higher value of crude protein, ash contents and moisture were observed in the Cirrhinus mrigala while fats and dry matter were higher in Labeo rohita. Our results of water contents are matching with the finding of Shakir (Shakir et al., 2013). They reported that water contents of Cirrhinus mrigala is higher than Labeo rohita and lower than Catla catla (Shakir et al., 2013). Similarly in another study conducted by Naz (Naz, 2013) the moisture contents were $74.02 \%$ for cultured Labeo rohita which is almost similar with our result of moisture contents for Labeo rohita (73.92\%). She reported $77.37 \%$ moisture contents in cultured Cirrhinus mrigala. Her comparative study of moisture contents shows similarity with our result that the moisture contents of cirrhinus mrigala are significantly higher than that of Labeo rohita (Naz, 2013).

The Fats contents are not significantly different in both of our experimental species and fats content was found in an inverse relation with water contents. Similar results were also observed by Love (Love, 1970). His resuts evaluate that a decrease in water content and increase in fat content of fish is attributed with a good condition, while the water content of a non-fatty muscle rises during nonfeeding or fasting conditions, due to utilization of protein for metabolic activities (Love, 1970). The possible reason for this is that the main constituent of muscle of the fish is moisture, which plays an important role in their metabolism. Water acts as a solvent and takes part in biochemical reaction in the fish body.

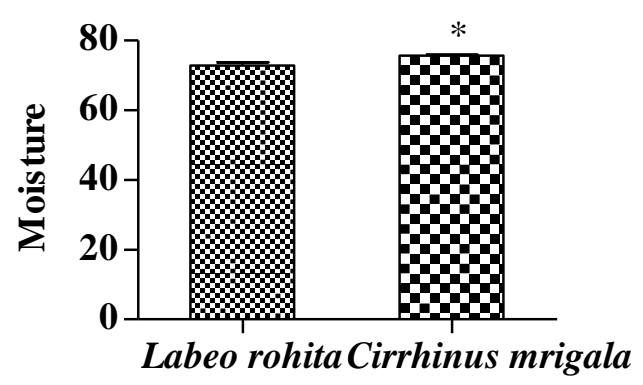

Figure 1 Moisture contents of Rohu and Mori. Statistical difference was considered when ${ }^{*} \mathrm{P}<0.05$

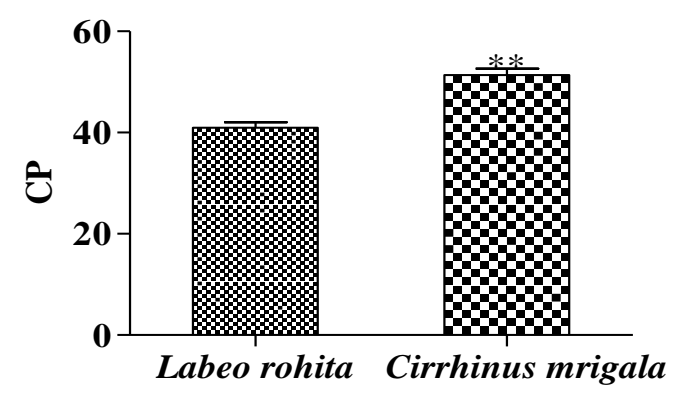

Figure $2 \mathrm{CP}$ contents of Rohu and Mori. Statistical difference was considered when ${ }^{* *} \mathrm{P}<0.001$

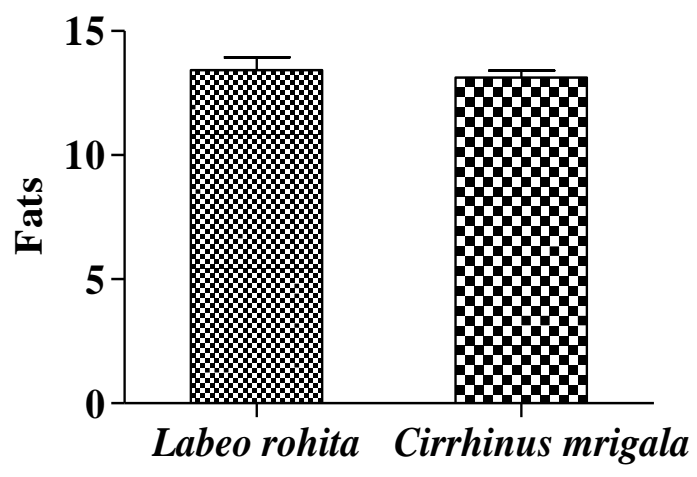

Figure 3 Fats contents of Rohu and Mori. Statistical difference was considered when ${ }^{*} \mathrm{P}<0.05$

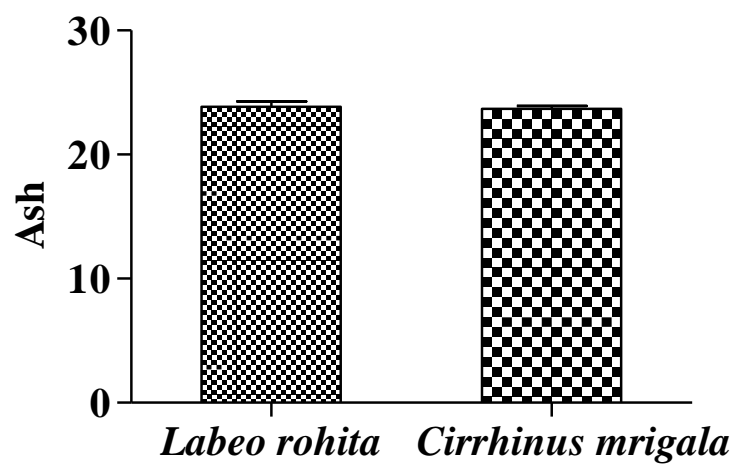

Figure 4 Ash contents of Rohu and Mori. Statistical difference was considered when ${ }^{*} \mathrm{P}<0.05$ 


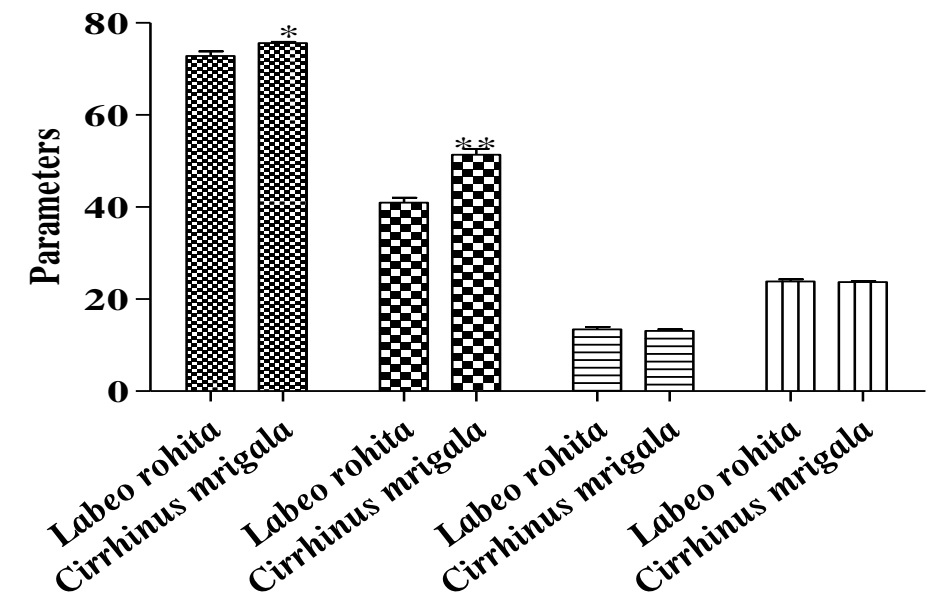

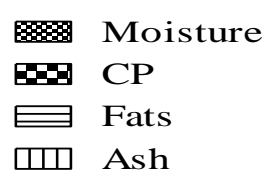

$\$ 8$ Moisture

Eats

एां Ash

Figure 5 Overall data representation of data. Significant differences were considered when ${ }^{*} \mathrm{P}<0.05$ and ${ }^{* *} \mathrm{P}<0.001$

Table 1 Data represented as Mean \pm SEM

\begin{tabular}{l|llll}
\hline \multicolumn{1}{c|}{ Fish Type } & Moisture & CP & Fats & Ash \\
\hline Labeo rohita & $72.823 \pm 0.981$ & $40.963 \pm 1.080$ & $13.429 \pm 0.507$ & $23.841 \pm 0.433$ \\
Cirrhinus mrigala & $75.644 \pm 0.288$ & $51.391 \pm 1.254$ & $13.127 \pm 0.277$ & $23.671 \pm 0.250$ \\
\hline
\end{tabular}

The water content of fish is varied within the limited range in various species (Afser et al., 1981). Similarly body moisture undergoes cyclic changes along with fattening of the body (Jana, 2014). In body composition water content or moisture content is an important attribute which is affected by pond ecosystems; fertilization (Hassan, 1996) feed ingredients (Javed et al., 1995), probiotics (Krishna, et al., 2009) and feeding rates (Hasan and Macintosh, 1993). Our result of Crude protein is in accordance with the results of Ali (Ali et al., 2005). They found crude protein in Cirrhinus mrigala (18.97\%) in comparison with Labeo rohita $(18.49 \%)$ is significantly higher while lower than Cyprinus carpio and catla catla (Ali et al., 2005). According to Love (1976), the process of spending protein in non-fatty fish is accompanied by an increase in moisture content. Mori showed higher protein level, which was probably due to their lower fat content (Grigorakis et al 2002). Naz (Naz, 2013) reported $20.97 \%$ in farmed Labeo rohita and $19.33 \%$ in farmed Cirrhinus mrigala. Our result of crude protein cannot match with Naz (2013) because she followed the procedure to find the contents on wet basis and we determined the crude protein on dry basis. Over result of ash contents that's are insignificant in both experimental species shows similarities with the results of Memon et al. They find out out the proximate body composition of Labeo rohita, Cirrhinus mrigala and Catla catla reared in a farm at Sukkur Pakistan. The ash contents of all the species were insignificant (Memon et al., 2011). In this work the ash contents were found similar in both experimental species and this is in agreement with the results of Shakir (Shakir et al 2013).

\section{Conclusion and Recommendations}

It is concluded from this work that Labeo rohita and Cirrhinus mrigala are very proteinaceous and have low fats contents so they are very good for the health of consumers. Further research is recommended on the other parameters and missing rays of this work.

\section{References}

Aberoumand A. 2012. Proximate composition of less known some processed and fresh fish species for determination of the nutritive values in Iran. J. Agri. Tech., 8(3): 917-922.

Adewoye SO, Fawole OO, Omotosho JS. 2003. Concentrations of selected elements in some fresh water fishes in Nigeria. Science Focus., 4: 106-108.

Afser MR, Ali F. 1981. Comparative study of body composition and caloric value of some air breathing fishes. The Indian Journal of Zoology., 22(2): 81-85.

Akhtar N. 2001. Strategic Planning for inland fisheries and aquaculture sector in Pakistan. In proceedings of National seminar on strategic planning for Fisheries and Aquaculture to face the challenges of new Millennium. Karachi-Pakistan.

Ali M, Iqbal F, Salam A, Iram S, Athar M. 2005. Comparative study of body composition of different fish species from brackish water pond. International Journal of Environmental Science \& Technology., 2(3): 229-232.

Ali SS, Narejo NT. 2009. Fundamentals of Ichthyology department of freshwater biology and fisheries, University of Sindh, Jamshoro.

AOAC. 1990. (Association of Official Analytical Chemist). Official methods of Analysis (15th ed.). Inc., Suite, 400, Arlington, Virginia.

AOAC. 2001. Association of official analytical chemists. Official methods of AOAC, 12th ed.Washington DC USA, Pp. 1142

Basade Y, Kapila S, Kapila R. 2000. Changes in muscle composition and energy contents of golden mahseer, Tor putitora (Hamilton) in relation to its spawning cycle. Indian J. Fish., 47(1): 37-41.

Dempson JB, Schwarz CJ, Shears M, Furey G. 2004. Comparative proximate body composition of Atlantic salmon with emphasis on parr from fluvial and lacustrine habitats. Journal of Fish Biology., 64(5): 1257-1271.

Devi KR, Ali A. 2011. Cirrhinus cirrhinus IUCN Red List of Threatened Species. Version 2012.2. International Union for Conservation of Nature. Retrieved., 9 May 2013.

Grigorakis K, Alexis MN, Taylor KA, Hole M. 2002. Comparison of wild and cultured gilthead sea bream (Sparus aurata); composition, appearance and seasonal variations. International journal of food science \& technology., 37(5): 477-484. 
Jana D. 2014. Effect of sew age on growth and muscle proximate composition of Indian major carp Labeo Rohita (Hamilton) (Doctoral dissertation, Kolkata).

Javaid MY, Salam A, Khan M N, Naeem M. 1992. Weight-length and condition factor relationship of a fresh water wild Mahaseer (Tor putitora) from Islamabad (Pakistan). In Proceeding of Pakistan Congress of Zoology., 12: 335-340.

Memon NN, Talpur FN, Bhanger MI, Balouch A. 2011. Changes in fatty acid composition in muscle of three farmed carp fish species (Labeo rohita, Cirrhinus mrigala, Catla catla) raised under the same conditions. Food Chemistry., 126(2): 405410.

Naz S. 2013. A comparative study of nutritional value among cultivated and wild Cyprinus carpio, Cirrhinus mrigala and Labeo rohita. M.Sc Thesis (unpublished) submitted to Department of Zoology, University of Peshawar.

Onyia LU, Milam C, Manu JM, Allison DS. 2010. Proximate and mineral composition in some freshwater fishes in upper River Benue, Yola, Nigeria. Continental Journal of Food Science and Technology., 4:1-6.
Pandey BN, Datta Munshi JS, Choubey BJ, Pandey PK. 1976. Seasonal variation in body composition in relation to breeding cycle of an air-breathing fish, Heteropneustes fossilis (Bloch). J. Inland Fish. Soc. India., 8: 91-95.

Sahu PK, Jena JK, Das P C, Mondal S, Das R. 2007. Production performance of Labeo calbasu (Hamilton) in polyculture with three Indian major carps Catla catla (Hamilton), Labeo rohita (Hamilton) and Cirrhinus mrigala (Hamilton) with provision of fertilizers, feed and periphytic substrate as varied inputs. Aquaculture., 262(2-4): 333-339.

Shakir HA, Qazi JI, Chaudhry AS, Hussain A, Ali A. 2013. Nutritional comparison of three fish species co-cultured in an earthen pond. Biologia (Pakistan)., 59(2): 353-358.

Umer K, Ali M, Iqbal R, Latif A, Naeem M, Qadir S, Iqbal F. 2011. Effect of various nutrient combinations on growth and body composition of rohu (Labeo rohita). African Journal of Biotechnology., 10(62): 13605-13609.

Watchman I I. 2000. Composition and Quality of fish, Edinburgh, Tory Research Station.

World Aquaculture. 2010. Contribution to food security. In: FAO Fisheries and Aquaculture Technical Paper., 500/1 120: 60120. 